семестрових комплексних тестових іспитів показують, що є ще багато студентів, які до навчання ставляться без потрібної наполегливості, а це недопустимо для майбутнього фахівця, від знань та вмінь якого залежатиме найцінніше - здоров' я людини.

Висновки: 1. Проведення семестрового комплексного тестового іспиту для студентів усіх факультетів та курсів є об' єктивною та незалежною складовою системи оцінювання знань студентів. Він органічно ввійшов у навчальний процес нашого університету і визнаний професорсько-викладацьким складом та студентами.

\section{Література}

1. Ковальчук Л. Я. Впровадження новітніх методик і систем навчального процесу в Тернопільському державному медичному університеті імені І. Я. Горбачевського / Л. Я. Ковальчук // Медична освіта. - 2009. -№ 2. - С. 10-14.
2. Поділ семестрового комплексного тестового іспиту на дві частини значно скорочує його тривалість, усуває створення надмірного навантаження та значної розумової втоми студентів і дозволяє їм показати дійсний рівень своїх знань.

3. Збільшення бази до п'ятисот тисяч тестових завдань, ситуаційних задач та рисунків не дозволяє зазубрювати відповіді, а вимагає щоденної грунтовної підготовки до занять та освоєння на високому рівні практичних навичок, які лежать в основі вирішення ситуаційних задач та розпізнавання рисунків.

2. Стандарти і рекомендації щодо забезпечення якості освіти у Європейському просторі вищої освіти. - К. : Ленвіт, 2006. - С.15-16.

3. Семестрові комплексні тестові іспити - надійний критерій оцінки знань студентів / І. Р. Мисула, В. П. Марценюк, К. О. Пашко, О. О. Стаханська // Медична освіта. - 2010. № 1.-C. 16-37.

УДК 378.147.001.76-057.85

\title{
ЯКІСТЬ ПІДГОТОВКИ ФАХІВЦІВ - ГОЛОВНА СКЛАДОВА БОЛОНСЬКОГО ПРОЦЕСУ
}

\author{
Ю. М. Колесник, Ю. М. Нерянов, В. М. Компанісць \\ Запорізький державний медичний університет
}

\section{THE QUALITY OF SPECIALISTS' TRAINING AS THE MAIN PART OF BOLOGNA PROCESS}

\author{
Yu. M. Kolesnyk, Yu. M. Neryanov, V. M. Kompaniyets \\ Zaporizhian State Medical University
}

\begin{abstract}
Якість - це основоположна умова для визнання, для довіри, сумісності та привабливості в європейському просторі. Моніторинг якості освіти має бути повним, постійним, прозорим, об’ сктивним; контроль якості повинен зосередитися не тільки на контролі навчального процесу, кадрів, науково-методичного забезпечення, матеріальної бази тощо, а, в першу чергу, на контролі знань студентів i, особливо, випускників, визначаючи їхню компетентність і спроможність задовольняти вимоги ринку праці. Якість підготовки фахівців визначається не тривалістю або змістом нав чання, а саме знаннями, вміннями і навичками, отриманими випускниками.

Наша освітянська стратегія мас бути максимально чітка і розрахована передусім на те, щоб зробити ринок освітніх послуг в Україні максимально авторитетним і престижним у світі, забезпечити визнання українського диплома за рубеежем.

Quality is the basic condition for appreciation, confidence, compatibility and attractiveness in the European space. Education quality monitoring should be complete permanent, clear and objective; quality should be focused not only on the educational process, stuff, scientific methodological facility, material basis, etc. But on the other hand, on the control of students' knowledge, especially graduates, identifying their competence and their capacity at the world work market. The quality of specialists' training is not determined by the duration or the content of the education, but by means of graduates' knowledge, skills.

Our educative strategy must be maximum clear and it is aimed first of all to make educational service market in Ukraine of the best authority and great prestige in the world to provide recognition of Ukrainian diploma abroad.
\end{abstract}

Вступ. Інтеграційний процес у науці й вищій освіті має дві складові: формування співдружності про- відних європейських університетів під егідою документа, названого Великою хартією університетів, та

(с) Ю. М. Колесник, Ю. М. Нерянов, В. М. Компанієць 
об’ єднання національних систем освіти і науки в європейський простір з єдиними вимогами, критеріями і стандартами. Головна мета цього процесу - консолідація зусиль наукової та освітянської громадськості й урядів країн Європи для істотного підвищення конкурентоспроможності європейської системи науки і вищої освіти у світовому вимірі. У межах цього простору мають діяти єдині вимоги до визнання дипломів про освіту, працевлаштування та мобільності громадян, що істотно підвищить конкурентоспроможність європейського ринку праці й освітніх послуг. Власне, цим документом було задекларовано прийняття загальної системи порівняльних освітньо-кваліфікаційних рівнів, зокрема через затвердження додатка до диплома; запровадження в усіх країнах формули триступеневої освіти; створення системи кредитів відповідно до європейської системи трансферу оцінок, включно з постійним навчанням; сприяння європейській співпраці щодо забезпечення якості освіти, розробка порівняльних критеріїв і методів оцінки якості; усунення перешкод на шляху мобільності студентів і викладачів у межах визначеного простору. Приділено особливу увагу важливості контролю і дотримання європейських стандартів якості освіти на усьому просторі.

Основна частина. На всіх етапах Болонського процесу було проголошено, що цей процес добровільний; полісуб'єктний; такий, що грунтується на цінностях європейської освіти і культури; такий, що не нівелює національні особливості освітніх систем різних країн Європи; багатоваріантний; гнучкий; відкритий; поступовий.

Але не слід ідеалізувати Болонський процес. Він нерівномірний, суперечливий, складний. Його цілі ще дуже гіпотетичні. Як приєднання до цього процесу, так і неприєднання мають свої переваги та ризики. Втім, з урахуванням усіх “за" i “проти” для країн, які прагнуть до економічного і суспільного розвитку i, зрештою, вступу до Свропейського Союзу (СС), альтернативи Болонському процесові немає.

Реформи, які ми повинні продовжувати, вже неможуть бути "косметичними". Вони мають стосуватися глибинних основ нашої освіти й науки. Здійснюючи їх, ми повинні будемо відповісти на запитання: чого і як слід навчати в сучасному світі гострої конкуренції? Тому нові виклики ми повинні прийняти не тільки переносячи на наше підгрунтя досвід інших держав, але й пропонуючи свої доробки, досягнення, пропозиції, своє бачення проблем. Тобто потрібно досягти гармонійного поєднання європейських нововведень і кращих вітчизняних традицій. Але ми повинні відверто визнати, що за останні роки у сфері вищої освіти України, особливо медичної, накопичуються складні проблеми, вирішення яких залишається на порядку денному, навіть незалежно від наявності чи відсутності такого фактора, як Болонський процес.

Ці проблеми погіршують розпізнавання нашої системи вищої медичної освіти зовнішнім світом, підсилюють ізоляціоністські тенденції, погіршують мобільність наших студентів, викладачів і науковців в межах європейського освітнього простору і ринку праці.

Зменшити ці перешкоди - означає для нас опинитися, образно кажучи, на першому поверсі величезної будівлі, яка має назву “Европа знань”. Головним на цьому шляху є модернізація системи контролю якості освіти.

Як визначено у “Саламанському зверненні”, якістьце основоположна умова для визнання, для довіри, сумісності та привабливості в європейському просторі. Берлінське комюніке визначає якість освіти як основу створення європейського простору.

Для нас важливими, зважаючи на сказане, є декілька положень: моніторинг якості освіти має бути повним, постійним, прозорим, об'єктивним; якість і акредитація, які міцно пов' язані між собою, висувають нові завдання щодо використання європейських стандартів якості, і тому наша участь в європейській мережі з гарантування якості у вищій освіті (система ENQA) обов' язкова; контроль якості повинен зосередитися не тільки на контролі навчального процесу, кадрів, науково-методичного забезпечення, матеріальної бази тощо, а, в першу чергу, на контролі знань студентів і особливо випускників, визначаючи їхню компетентність і спроможність задовольняти вимоги ринку праці; окрім внутрішньої оцінки якості неминуча зовнішня оцінка, яку підтримує ENQA і яка надає можливість оцінювати навчальні програми за межами своєї країни за загальними критеріями.

Болонський процес - це процес розпізнавання однієї освітньої системи іншою в європейському просторі. Якщо майбутнє України пов' язане з Свропою, то не можна надалі стверджувати, що Болонський процес має для нас лише просвітнє та пізнавальне значення. Надання високої оцінки національній системі освіти не має заспокоювати нас і стримувати глибинне іï реформування.

Нині можна 3 жалем констатувати, що незважаючи на природні досягнення освіти, які забезпечує нова соціополітична система (демократичність, гнучкість, незаідеологізованість), в масовому вимірі освіта стала менш якісною, а переважна більшість випускників вищих навчальних закладів (особливо нових) не зовсім конкурентоспроможна на європейському ринку праці. Це зобов' язує менше говорити про власні 
досягнення, а все білыше аналізувати світові та європейські тенденції реформування освіти і відповідно до цього напружено і послідовно вдосконалювати нашу професійну сферу діяльності.

Водночас участь системи вищої медичної освіти України в болонських перетвореннях має бути спрямована лише на іiі розвиток і набуття нових якісних ознак, а не на втрату кращих традицій, зниження національних стандартів її якості. Орієнтація на Болонський процес не має призводити до надмірної перебудови вітчизняної системи медичної освіти. Навпаки, iii стан треба глибоко осмислити, порівнявши з європейськими критеріями і стандартами, та визначити можливості їі вдосконалення на новому етапі. При цьому еволюцію системи освіти не слід відокремлювати від інших сфер суспільства. Вона має розвиватися в гармонійному взаємозв' язку з суспільством в цілому, беручи на себе роль його провідника.

Модернізація системи вищої освіти в Україні (Закон "Про вищу освіту" та його новий проект, ряд нормативних актів МОН та МО3 України) має деякі спільні ознаки з Болонським процесом, алеза більшістю напрямів вона йому не відповідає. Це пов'язано $з$ тим, щовихідні концепції такої модернізації не були зорієнтовані на інтегрування національної системи освіти в Свропейський простір. Вони більшою мірою мали “внутрішній” характер і переважно зводилися до “прилаштування” системи вищої освіти до нових внугрішніх реалій. На сучасному етапі концепцію реформування вищої медичної освіти слід докорінно переглянути і створити програму послідовного її зближення з європейським освітнім і науковим простором.

Дарма, що в системі освіти України, як і колишнього СРСР, ніколи не бракувало чудових педагогів, досконалих методик чи здібних учнів, студентів. Але саме те, що об'єднувальною для шести основних ключових позицій Болонської декларації є якість освіти, потребує поглянути на це питання дещо з іншого боку. Проблема полягає в тому, що якість підготовки фахівців безпосередньо залежить від умов навчання, професорсько-викладацького складу, від матеріальної бази вищих закладів освіти - це відомо без будь-якої інтеграції. Інша справа - чи можемо ми за цими складовими нарівно конкурувати з вищими закладами тих країн, які нині в освіту вкладають незалишкові кошти, а 20 \% і більше від валового внутрішнього продукту (США, Японія, Німеччина, Англія та ін.).

Щоб визначити якість підготовки фахівців, треба брати до уваги не тривалість або зміст навчання, а саме знання, вміння і навички, отримані випускниками. Зазначимо, що саме завдяки великій увазі до формування не лише знань, а й вмінь та навичок, індивідуалізації навчання національна система медичної освіти не лише втрималася від остаточного зруйнування, а й успішно розвивається нині. Інша справа, що індивідуалізувати навчання, перейти до таких прогресивних форм організації навчального процесу, як дистанційна, кореспондентська, не дають змоги скромні матеріальні можливості вищих закладів освіти, через що вони не можуть максимально розширити комп'ютерну мережу, використовувати телебачення, Інтернет тощо. На цьому шляху ЗДМУ є одним 3 піонерів і ректорат приділяє особливу увагу новітнім технологіям навчання, зміцненню матеріально-технічної бази. Тільки за останні три роки в університеті втричі виріс комп'ютерний парк сучасних ПЕОМ, майже вшестеро - відеосупроводжувальна техніка (мультимедійними засобами, плазмовими панелями обладнані всі аудиторії, як на території університету, так і на клінічних базах). Активно розвивається дистанційне навчання на післядипломному етапі та на заочній формі підготовки фахівців у фармації. Очікувати ж від держави на допомогу у вирішенні подібних питань нині через економічні проблеми не доводиться. Отож і використати європейські, американські, інші прогресивні навчальні технології у повному обсязі ближчим часом навряд чи вдасться.

Висновки. 3 погляду методології інтеграційних процесів в освіті України загалом кардинально постає питання такої організації процесу підготовки спеціаліста, коли він, сприймаючи світове, загальне, не відкидає власного, специфічного, національного. Це сьогодні торкається нелише медичної освіти, а й усієї духовної сфери та, власне, й інших сфер життя. Тут не йдеться про якийсь егоцентризм, самоізоляцію. Навпаки, в Свропу, у світовий простір кожна свідома нація намагається будь-що інтегруватися 3 власними особливостями, дбає про те, щоб ці особливості сприйняли і визнали інші народи, нації.

Отже, будь-яка інтеграція України у світ, Свропу, в тому числі й освітня, не є самоціллю. До Болонського процесу треба прямувати не формальним шляхом, не задля того, щоб слугувати комусь, працювати, умовно кажучи, на Європу. Наша медична освітянська стратегія має бути максимально чітка і розрахована передусім на те, щоб зробити ринок освітніх послуг в Україні максимально авторитетним і престижним у світі, забезпечити визнання українського диплома за кордоном. У результаті це забезпечить не лишевітчизняніпотреби у фахівцях, а й підвищить авторитет, імідж України у світі. І тут набором певних, найкращих заходів справі незарадиш. Потрібні радикальні дії хоча б з тих проблем, які ми порушили. 